\title{
Erratum to: Transpressional regime in southern Arabian Shield: Insights from Wadi Yiba Area, Saudi Arabia
}

\author{
Zakaria Hamimi $^{1} \cdot$ Mohamed El-Shafei $^{1,2} \cdot$ Ghazi Kattu $^{3} \cdot$ Mohammed Matsah $^{1}$
}

Published online: 11 March 2017

(C) Springer-Verlag Wien 2017

Erratum to: Miner Petrol (2013) 107:849-860

DOI 10.1007/s00710-012-0198-6

The original version of this article unfortunately contained a mistake. The 2nd affiliation of the 2nd author, Mohamed El-Shafei was missing. The correct affiliations are given below.

Zakaria Hamimi

yahiahamimi@gmail.com

1 Department of Structural Geology and Remote Sensing,

Faculty of Earth Sciences, King Abdulaziz University,

Jeddah, Saudi Arabia

2 Geology Department, Faculty of Science, Suez Canal University,

Ismailia, Egypt

3 Saudi Geological Survey,

Jeddah, Saudi Arabia 